\title{
Quality of steak restructured from beef trimmings containing microbial transglutaminase and impacted by freezing and grading by fat level
}

\author{
Supaluk Sorapukdee ${ }^{1, *}$ and Pussadee Tangwatcharin ${ }^{1}$
}

\author{
* Corresponding Author: Supaluk Sorapukdee \\ Tel: +66-2-3298000 (6052), Fax: +66-2-3298519, \\ E-mail: supaluk.so@kmitl.ac.th \\ 'Department of Animal Production Technology and \\ Fisheries, Faculty of Agricultural Technology, King \\ Mongkut's Institute of Technology Ladkrabang, \\ Bangkok 10520, Thailand \\ ORCID \\ Supaluk Sorapukdee \\ https://orcid.org/0000-0001-8082-1164 \\ Pussadee Tangwatcharin \\ https://orcid.org/0000-0002-8151-7014
}

Submitted Mar 5, 2017; Revised Jun 3, 2017; Accepted Jul 6, 2017
Objective: The objective of this research was to evaluate the physico-chemical, microbiological and sensorial qualities of restructured steaks processed from beef trimmings (grade I and II) and frozen beef (fresh beef as control and frozen beef).

Methods: Beef trimmings from commercial butcher were collected, designated into 4 treatments differing in beef trimmings grade and freezing, processed into restructured steaks with $1 \%$ microbial transglutaminase and then analyzed for product quality.

Results: The results showed that all meat from different groups could be tightly bound together via cross-linking of myosin heavy chain and actin as observed by sodium dodecyl sulfate-polyacrylamide gel electrophoresis. Microbial counts of psychrotrophic and mesophilic bacteria were not affected by treatments ( $\mathrm{p}>0.05)$, and no detectable of thermophilic bacteria were found. Regarding effect of beef trimmings grade, steaks made from beef trimmings grade II (16.03\% fat) showed some superior sensorial qualities including higher tenderness score $(p<0.05)$ and tendency for higher scores of juiciness and overall acceptability $(p<0.07)$ than those made from beef trimmings grade I ( $2.15 \%$ fat). Moreover, a hardness value from texture profile analysis was lower in steaks processed from beef trimmings grade II than those made from grade I ( $p<$ 0.05). Although some inferior qualities in terms of cooking loss and discoloration after cooking were higher in steaks made from beef trimmings grade II than those made from beef trimmings grade I $(p<0.05)$, these differences did not affect the sensory evaluation. Frozen beef improved the soft texture and resulted in effective meat binding as considered by higher cohesiveness and springiness of the raw restructured product as compared to fresh beef $(\mathrm{p}<0.05)$.

Conclusion: The results indicated the most suitable raw beef for producing restructured steaks without detrimental effect on product quality was beef trimmings grade II containing up to $17 \%$ fat which positively affected the sensory quality and that frozen beef trimmings increased tenderness and meat binding of restructured beef steaks.

Keywords: Restructured Meat; Transglutaminase; Beef; Fat Content; Freezing

\section{INTRODUCTION}

The demand for beef consumption was growing worldwide at an estimated $0.37 \%$ per year during 2010 thorugh 2014 [1]. Additionally, the increasing costs of beef production have prompted the industry to develop strategies to utilize low-value meat cuts and beef trimmings to generate additional revenue. Restructured meat, prepared from small cuts of meat in an effort to increase the yield of marketable products, offers many advantages for both consumer and the meat industry. Since there is no added sodium chloride or phosphates and uses commercial microbial transglutaminase (MTGase) as a binding agent, restructured meat products are considered 'healthy' as reported by Kuraishi et al [2].

MTGase is an enzyme promoting protein binding in muscle foods through covalent cross- 
linking between glutamine and lysine residues, resulting in the formation of high molecular weight polymers [3]. MTGase is active at the $\mathrm{pH}$ range 5 to 8 and temperature range $2^{\circ} \mathrm{C}$ to $6^{\circ} \mathrm{C}$. This enzyme is widely utilized for the restructuring of meat by binding together small pieces of meat and the quality of product can be varied depended on intrinsic properties of meat like muscle fiber type [4] meat particle size [5], alignment of muscle fiber [6], and post-mortem aging time [7] as well as extrinsic factors of non-meat ingredients and processing conditions [8]. However, the quality of products containing MTGase as impacted by beef trimmings grade and frozen beef has not been evaluated.

Generally, the quality of beef trimmings is classified based on the maximum amount of fat that it is allowed to contain, which differs between countries. According to Heinz and Hautzinger [9], there are three grades of manufacturing meat from cattle including grade B1 (lean beef without visible fat), grade B2 (less than $10 \%$ fat) and grade B3 (less than $20 \%$ fat), which beef trimmings with higher fat content are classified as lower-grade meat due to larger amounts of visible connective tissue. In Thailand, Sethakul and Sivapirunthep [10] categorized beef trimmings into 5 groups including RI, RII, RIII, RIV and RV that contained $5 \%, 10 \%, 15 \%$, $30 \%$, and $35 \%$ fat content, respectively. Several studies have shown that increased fat levels increase consumer acceptance of fresh beef steaks $[11,12]$. However, for restructured meat in which fat can interfere with meat binding, it is essential to evaluate which grades of beef trimmings can be formulated with enhanced product quality or at least no detrimental impact on product quality.

Frozen meat has an advantage over fresh meat with increased storage time and a greater flexibility in inventory for retailers [13], but it reduces meat quality. The cell membranes of meat are damaged upon freezing which results in a lower water-holding capacity and a higher cooking loss [13] and the consequently production of less juicy meat [14]. Therefore, the aim of the present experiment was to evaluate the quality of restructured beef steak in terms of physico-chemical, microbiological and sensorial properties as influenced by the use of beef trimmings grades and frozen beef.

\section{MATERIALS AND METHODS}

\section{Collection of beef trimmings}

Fresh beef trimmings were obtained from sirloin and round portions with two commercial-quality grades; beef trimmings grade I (lean with fat content up to 10\%) and grade II (lean with fat content up to 20\%) (Figure 1). These samples were collected from a commercial butcher, Pon Yang Kham Livestock Breeding Cooperatives NSC Ltd., Pathumthani, Thailand. Beef trimmings were transported on ice to the meat laboratory of the Department of Animal Production Technology and Fisheries, King Mongkut's Institute of Technology Ladkrabang (KMITL) within $4 \mathrm{~h}$ for further processing. Then, beef trimmings grades I and II were analyzed for meat $\mathrm{pH}$ and proximate composition.
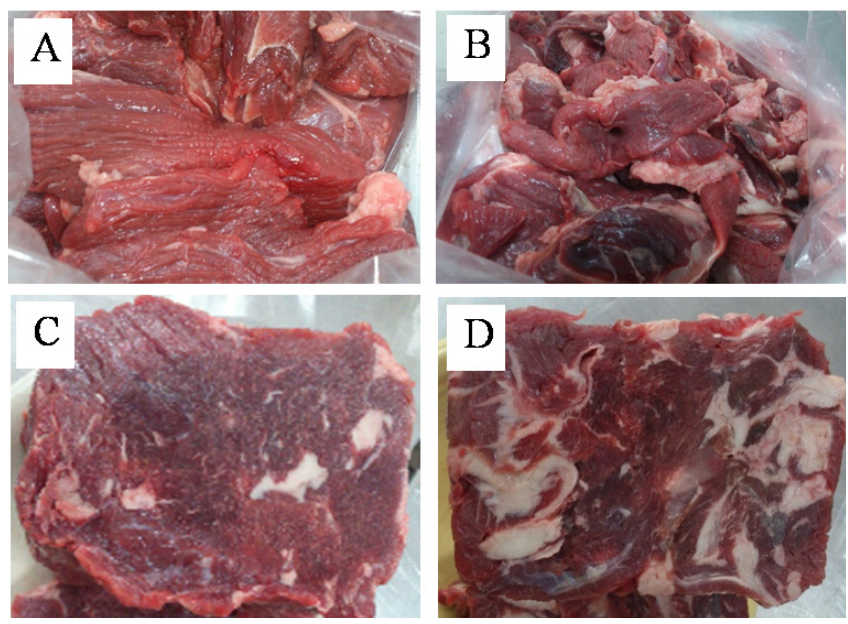

Figure 1. Beef trimmings grade I (A) and grade II (B). Obtained raw restructured steaks from beef trimmings grade I (C) and grade II (D).

\section{Ultimate $\mathrm{pH}$ of beef trimmings}

The ultimate $\mathrm{pH}$ of meat was directly measured at three different locations using portable $\mathrm{pH}$ meter (Mettler Toledo SevenGo SG2, Mettler Toledo, Schwerzenbach, Switzerland).

Determination of proximate composition of beef trimmings Moisture, protein, fat and ash contents of beef trimmings were analyzed according to the method of AOAC [15]. The values were expressed as \% (wet weight basis). Triplicate determinations were done for each meat.

Experimental design and preparation of restructured beef To study effects of beef trimmings grade (grade I and II) and frozen beef (fresh as a control and frozen beef) on the resulting quality of restructured beef, a total of 4 different treatments were performed. Each type of beef trimmings was divided into two groups. The first group of the sample was chilled at $4^{\circ} \mathrm{C}$ for $24 \mathrm{~h}$ and assigned to fresh samples. The residual sample was frozen at $-20^{\circ} \mathrm{C}$ for 1 month and then thawed with running tap water until attained $4^{\circ} \mathrm{C}$ of core temperature (CT), which was simulated as freeze-thawed beef or frozen samples. Thereafter, 4 different restructured beef steaks were formulated as shown in Table 1. Cold-set restructured beef steaks were made according to the procedure of Farouk et al [6] with some modification. Briefly, beef trimmings were striped into about $20 \times 60 \times 10 \mathrm{~mm}$ and a $2-\mathrm{kg}$ restructured beef was manufactured. The samples $(2-\mathrm{kg})$

Table 1. Treatment formulation of restructured steaks

\begin{tabular}{lllccc}
\hline Effect & & & \multicolumn{3}{c}{ Ingredients (\% w/w) } \\
\cline { 1 - 2 } \cline { 5 - 6 } Beef trimmings & Freezing & & Meat & MTGase & Chilled water \\
\hline Grade I & Fresh beef & & 96.0 & 1.0 & 3.0 \\
Grade I & Frozen beef & & 96.0 & 1.0 & 3.0 \\
Grade II & Fresh beef & & 96.0 & 1.0 & 3.0 \\
Grade II & Frozen beef & & 96.0 & 1.0 & 3.0 \\
\hline
\end{tabular}

MTGase, microbial transglutaminase. 
were thoroughly mixed with $3 \%(\mathrm{w} / \mathrm{w})$ of chilled water and $1 \%$ (w/w) of MTGase (ACTIVA TG-B Powder Sprinkle QS-Type, Ajinomoto Co., Ltd., Bangkok, Thailand) using a bowl-lift stand mixer (KitchenAid, Professional 600, St. Joseph, MI, USA) for $4 \mathrm{~min}$ at a speed setting of 2 . The resulting mixture was stuffed into a stainless steel ham mould/press. The stuffed moulds were held for $6^{\circ} \mathrm{C}$ to $8^{\circ} \mathrm{C}$ for $4 \mathrm{~h}$ to allow the binder to bind the restructured meat pieces. The reformed meats were removed from mould and then packed in vacuum bags and stored at $-20^{\circ} \mathrm{C}$ until analysis. A frozen sample was semi-thawed to the temperature of $-2^{\circ} \mathrm{C}$ to $0^{\circ} \mathrm{C}$ and then sliced into a 20 -mm thick steaks for further analysis. Three replications of each treatment were made to determine differences among batches $(\mathrm{n}=3)$.

\section{Sodium dodecyl sulfate-polyacrylamide gel electrophoresis} Protein pattern of raw beef and resulting raw restructured beef was determined by sodium dodecyl sulfate-polyacrylamide gel electrophoresis (SDS-PAGE) using 4\% stacking and 10\% running gels according to the method of Laemmli [16]. To solubilize the sample, $27 \mathrm{~mL}$ of $5 \%(\mathrm{w} / \mathrm{v})$ SDS were added into $3 \mathrm{~g}$ of sample. Mixtures were homogenized for $1 \mathrm{~min}$ at a speed of 12,000 rpm and incubated at $85^{\circ} \mathrm{C}$ for $1 \mathrm{~h}$ to dissolve total proteins followed by centrifuging the samples at $3,500 \mathrm{~g}$ for $20 \mathrm{~min}$ to remove undissolved debris. Dissolved protein was frozen and stored at $-20^{\circ} \mathrm{C}$ until analysis. Proteins $(15 \mu \mathrm{g})$ determined by the Lowry method [17] were loaded onto the gel and subjected to electrophoresis at a constant current of $20 \mathrm{~mA}$ per gel using a vertical gel electrophoresis, miniPAGE chamber AE-6530 (ATTO Corporation, Tokyo, Japan). After separation, the protein bands were stained overnight using $0.125 \%(\mathrm{w} / \mathrm{v})$ Coomassie Brilliant Blue R-250 in $45 \%(\mathrm{v} / \mathrm{v})$ ethanol and $10 \%(\mathrm{v} / \mathrm{v})$ acetic acid. Destaining was performed using 30\% (v/v) methanol and 10\% (v/v) acetic acid.

\section{Cooking loss}

Eight pieces of raw steaks per treatment were weighed and grilled in a pan until the $\mathrm{CT}$ reached $71^{\circ} \mathrm{C}$, as monitored by probes of Type-K thermocouple from a digital thermometer (52 Series II, Fluke Corp., Everett, WA, USA). Cooked steaks were cooled for $30 \mathrm{~min}$ at $25^{\circ} \mathrm{C}$ and weighed. Cooking loss was calculated from the differences in the weight of raw and cooked steaks and expressed as the percentage of initial weight. Cooked steaks were used to further analysis of color, instrumental texture, microbiological analysis and sensory evaluation.

\section{Color measurement}

The color of four samples from raw and cooked restructured steaks was measured in the $\mathrm{L}^{*} \mathrm{a}^{*} \mathrm{~b}^{*}$ mode of Commission Internationale de l'Eclairage (CIE) by a color measurement spectrophotometer (MiniScan EZ, HunterLab, Reston, VA, USA). Three locations per sample were carried out and the resulting average was used in data analysis, where the data was expressed as CIE $\mathrm{L}^{*}$ (lightness), $\mathrm{a}^{\star}$ (redness), and $\mathrm{b}^{\star}$ (yellowness).

\section{Warner-Bratzler shear force}

The Warner-Bratzler shear force (WBSF) was determined in raw and cooked restructured steaks. Ten rectangular cube samples for each steak $(10 \mathrm{~mm} \times 10 \mathrm{~mm} \times 25 \mathrm{~mm})$ were taken. Each sample was sheared with a WBSF device attached to an Instron universal testing machine (3344, Instron Engineering Corp., Canton, MA, USA) with a $50-\mathrm{kg}$ load cell using a crosshead speed of $60 \mathrm{~mm} / \mathrm{min}$. The maximum force $(\mathrm{N})$ was recorded.

\section{Texture profile analysis}

The raw and cooked steaks were subjected to texture profile analysis (TPA) [18] using an Instron universal testing machine model 3344 with a compression plate surface. Steaks at $25^{\circ} \mathrm{C}$ were cut into 10 cube samples $(20 \times 20 \times 20 \mathrm{~mm})$ and placed on the instrument's base. TPA textural parameters were measured at room temperature with the following testing conditions: crosshead speed was $60 \mathrm{~mm} / \mathrm{min}$ and compressed twice to $40 \%$ of their original height. The Bluehill 2 software (Instron Engineering Corp., USA) was used to collect and process the data. TPA analyses were defined and calculated as previously described by Bourne [18]. Hardness $(\mathrm{N})$, cohesiveness (ratio), gumminess $(\mathrm{N})$, springiness (ratio), and chewiness $(\mathrm{N})$ were calculated from the force-time curves generated for each sample.

\section{Microbiological analysis}

Aerobic bacteria counts of raw and cooked steaks from 4 treatments were carried out. Each sample ( $25 \mathrm{~g}$ ) was transferred into $225 \mathrm{~mL}$ of $0.85 \% \mathrm{NaCl}$ and homogenized for $2 \mathrm{~min}$ with the Stomacher BagMixers 400 VW (Interscience Co., Saint-Nom-laBretèche, France). Appropriate ten-fold dilutions of the samples were prepared in $0.85 \% \mathrm{NaCl}$ and dropped on growth media in duplicate to estimate microbial counts. Total psychrotrophic, mesophilic and thermophilic aerobic populations were estimated on plate count agar (PCA) incubated at $7^{\circ} \mathrm{C}$ for 10 days, $37^{\circ} \mathrm{C}$ for 24 to $48 \mathrm{~h}$ and $55^{\circ} \mathrm{C}$ for 3 days, respectively. The number of colonies was counted and expressed as logarithms of colony forming units per gram (Log CFU/g) [19].

\section{Sensory evaluation}

Sensory attributes of cooked steaks in regard to color, appearance, flavor, tenderness, juiciness and overall acceptability of the sample, were evaluated by 30 semi-trained panelists from undergraduate and graduate students of Department of Animal Production Technology and Fishery, KMITL using a seven-point hedonic scale. A score ranged from 1 to 7 with the following ratings: 7 = liked extremely, 6 = liked moderately, $5=$ liked slightly, 4 = Indifferent, 3 = slightly disliked, $2=$ moderately disliked, and $1=$ disliked extremely. Unsalted crackers and water were supplied to testers to refresh their palates before tasting subsequent samples.

\section{Statistical analysis}

In an analysis of $\mathrm{pH}$ and proximate composition of beef trimmings 
grade I and II, results were subjected to independent-samples t-tests for comparison of means between the two groups. To study the effects of beef trimmings grade, frozen beef and their interaction, the data were analyzed by the general linear model procedure. Least squares means were computed and separated $(p<0.05)$ using the PDIFF option of GLM. All statistical analyses were performed using SAS v. 9.0 (SAS Inst. Inc., Cary, NC, USA) [20].

\section{RESULTS AND DISCUSSION}

\section{Proximate composition and $\mathrm{pH}$ of beef trimmings}

The appearance of beef trimmings grade I and II is shown in Figure $1 \mathrm{~A}$ and $1 \mathrm{~B}$. Among several grades of beef trimmings obtained from a commercial butcher during the manufacture of different primal beef cuts, these collected samples were considered as the top two grades of trimmings by-product due to less visible fat and connective tissue than other trimmings. Chemically, beef trimmings grade I showed higher moisture, protein and ash contents with a lower fat content compared to grade II $(\mathrm{p}<0.05)$ (Table 2). Beef trimmings grade I containing $75.65 \%$ moisture, $21.16 \%$ protein, $2.15 \%$ fat, and $1.07 \%$ ash. While beef trimmings grade II had $64.52 \%$ moisture, $17.59 \%$ protein, $16.03 \%$ fat, and $0.87 \%$ ash.

The $\mathrm{pH}$ of beef trimmings grade I was lower than those from grade II ( $\mathrm{p}<0.05)$ (Table 2), which expressed as 5.7 and 6.0, respectively. The higher $\mathrm{pH}$ of beef trimmings grade II rather than grade I might be due to its high-fat content. These results are in agreement with Daszkiewicz et al [21], who reported that high intramuscular fat had a beneficial effect on the $\mathrm{pH}$ (high $\mathrm{pH}$ ) of beef due to an insufficient post-slaughter acidification of meat.
Table 2. Proximate composition and $\mathrm{pH}$ of beef trimmings from different grades

\begin{tabular}{lcc}
\hline \multirow{2}{*}{ Parameters } & \multicolumn{2}{c}{ Beef trimmings } \\
\cline { 2 - 3 } & $75.65 \pm 0.08^{\mathrm{a}, 1)}$ & \multicolumn{1}{c}{ Grade II } \\
\hline Moisture (\%) & $21.16 \pm 0.02^{\mathrm{a}}$ & $17.52 \pm 2.09^{\mathrm{b}}$ \\
Protein (\%) & $2.15 \pm 0.34^{\mathrm{b}}$ \\
Fat (\%) & $1.07 \pm 0.00^{\mathrm{a}}$ & $16.03 \pm 0.26^{\mathrm{a}}$ \\
Ash (\% & $5.70 \pm 0.20^{\mathrm{b}}$ & $0.87 \pm 0.01^{\mathrm{b}}$ \\
$\mathrm{pH}$ & $6.00 \pm 0.10^{\mathrm{a}}$ \\
\hline${ }^{1)}$ Values are given as means \pm standard deviation. \\
${ }^{\mathrm{a}, \mathrm{b}}$ Different superscripts in the same row indicate significant differences among treat- \\
ments $(p<0.05)$.
\end{tabular}

\section{Protein pattern}

SDS-PAGE protein patterns of raw beef and restructured beef prepared from different treatments are depicted in Figure 2A and 2B. For raw beef samples, without MTGase, the highest band intensity of myosin heavy chain (MHC, $200 \mathrm{kDa}$ ) and actin (42 $\mathrm{kDa}$ ) was found in all beef in both non-reducing and reducing condition (Figure 2A). There were no differences in protein patterns between treatments (beef trimmings grade and frozen beef) either without (Figure 2A) or with MTGase (Figure 2B). However, a SDS-PAGE analysis was a benefit to investigate the potential formation of both fragmented and cross-linked products. Under reducing conditions, reducing agents (such as $\beta$-mercaptoethanol in present study) is incorporated into the SDS-containing loading buffers that reduce disulfide bridges in proteins and then allow protein subunit separation, resulting in new bands appearing after SDS-PAGE [22]. While disulfide-linked proteins are not broken under non-reducing conditions. For the restructured samples in the present study that were separated under non-reducing
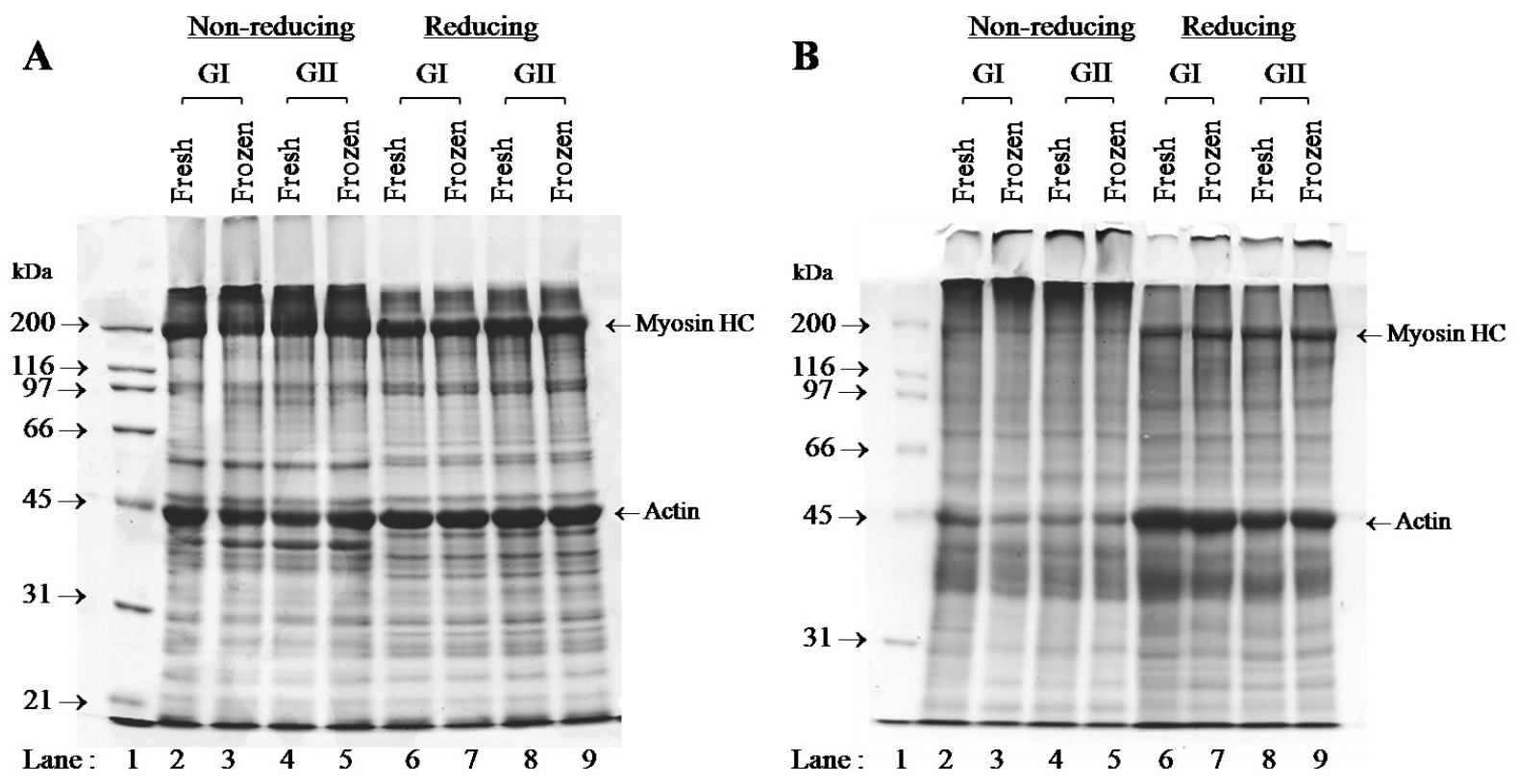

Figure 2. Electrophoretic patterns of muscle protein from raw beef (A) and raw restructured beef steaks containing microbial transglutaminase (B) separated by $10 \%$ running gel. $\mathrm{Gl}$, Beef trimmings grade I; GII, Beef trimmings grade II. 
conditions (Figure 2B, Lane 2-5), a high molecular weight protein above $200 \mathrm{kDa}$ and the newly formed protein was observed on the top of resolving gel, while MHC and actin were seen as small and faded bands. On the other hand, regarding Figure 2B, Lane 6-9, MHC cloud was partially reproduced (lower intensity as compared to raw beef samples) and actin seemed to be completely reproduced under reducing conditions (same intensity as compared to raw beef samples). These results indicating that MTGase enzyme could induce cross-linking of polypeptide chains through disulfide bonds. Qin et al [23] also reported that the MTGase cross-linking reaction promoted the formation of disulfide bonds of soybean protein isolate and wheat gluten mixture gels. Furthermore, regarding restructured steak, it was noted that under reducing conditions, bands of a high molecular weight protein above $200 \mathrm{kDa}$ and an aggregated protein on the top of resolving gel did not completely disappear. This result suggested that non-disulfide bonds of MHC also participated in stabilizing the reformed beef. Kumazawa et al [24] reported that the intensity of MHC band under reducing condition was reduced gradually as the amount of added MTGase increased, which might be due to non-disulfide covalent cross-linking of the MHC molecules. In surimi gel, MTGase induced the formation of non-disulfide covalent bonds [25], which resulted in the formation of MHC cross-linking and subsequently, a strong gel [26]. As reviewed by
Yokoyama et al [27], myosin and actin could be covalently crosslinked by MTGase. Therefore, protein cross-links reaction among restructured beef products with adding MTGase might be supported by both disulfide and non-disulfide bonds of MHC (reducible and non-reducible cross-links under reducing condition, respectively), and also disulfide bond of actin (markedly reducible crosslinks under reducing condition) in restructured beef samples. Finally, in the present study, beef trimmings both grade I and II either fresh or frozen could be tightly bound together via cross-linking of MHC and actin, leading to satisfactory obtained restructured products as shown in Figure 1C and Figure 1D, respectively.

\section{Physical characteristics}

Restructured products processed from beef trimmings grade II (belonging high-fat content) showed higher cooking loss value than grade I (Table 3). The results are in agreement with Tornberg et al [28] who concluded that fat was more easily removed during cooking from higher fat beef burgers. Theoretically, weight loss during cooking is due to the losses of both water (and water-soluble components) and fat [29]. From research using microscopy, fat loss from meat products depends on two factors. The first is the instability of the fat itself and the other factor is the ability of the fat to translocate from the inner to the outer parts of the product

Table 3. Physical characteristics of raw and cooked restructured beef steaks containing MTGase

\begin{tabular}{|c|c|c|c|c|c|c|c|}
\hline \multirow{2}{*}{ Parameters } & \multicolumn{3}{|c|}{ Beef trimmings } & \multicolumn{3}{|c|}{ Freezing } & \multirow{2}{*}{ SEM } \\
\hline & Grade I & Grade II & p-value ${ }^{1)}$ & Fresh & Frozen & $p$-value ${ }^{1)}$ & \\
\hline Cooking loss & $32.24^{21}$ & 37.74 & 0.002 & 34.95 & 35.03 & 0.948 & 0.85 \\
\hline CIE L* & 38.66 & 46.36 & $<0.001$ & 42.12 & 43.91 & 0.058 & 0.60 \\
\hline CIE a* & 17.55 & 16.42 & 0.034 & 16.99 & 16.97 & 0.958 & 0.25 \\
\hline CIE b* & 15.10 & 15.58 & 0.045 & 15.17 & 15.52 & 0.107 & 0.12 \\
\hline Cohesiveness (ratio) & 0.50 & 0.52 & 0.349 & 0.48 & 0.53 & 0.043 & 0.01 \\
\hline Gumminess (N) & 1.63 & 1.44 & 0.110 & 1.92 & 1.15 & $<0.001$ & 0.11 \\
\hline Springiness (ratio) & 0.91 & 0.92 & 0.094 & 0.90 & 0.93 & $<0.001$ & 0.01 \\
\hline Chewiness (N) & 1.60 & 1.22 & 0.006 & 1.68 & 1.14 & $<0.001$ & 0.09 \\
\hline \multicolumn{8}{|l|}{ Cooked attributes } \\
\hline Shear force (N) & 5.60 & 5.09 & 0.318 & 6.41 & 4.27 & $<0.001$ & 0.34 \\
\hline Hardness (N) & 23.32 & 19.29 & 0.023 & 22.91 & 19.70 & 0.063 & 1.17 \\
\hline Cohesiveness (ratio) & 0.62 & 0.64 & 0.141 & 0.62 & 0.64 & 0.293 & 0.01 \\
\hline Gumminess (N) & 11.40 & 13.19 & 0.055 & 12.60 & 11.99 & 0.496 & 0.62 \\
\hline Springiness (ratio) & 0.91 & 0.92 & 0.273 & 0.91 & 0.91 & 0.614 & 0.01 \\
\hline Chewiness (N) & 12.68 & 12.10 & 0.521 & 12.72 & 12.06 & 0.470 & 0.65 \\
\hline
\end{tabular}

SEM, standard error of mean; CIE, Commission Internationale de I'Eclairage.

No interaction effect of beef trimmings $\times$ freezing was observed in these analyzed parameters $(p>0.05)$.

1) Statistical significance after applying general linear model procedure.

2) Values are given as least squared mean.

${ }^{3)}$ Color differences among raw and cooked steaks. 
[29]. In some cases, the solubilization of collagen during cooking may allow melted fat to diffuse along channels. Consequently, this loss occurs due to an expansion of fat droplets as they melt and the formation of pools and channels [29]. The percent of cooking loss increased as the fat level on the ground beef patties increased from $5 \%$ to $30 \%$ was also reported by Troutt et al [30]. On the contrary, the dense protein matrix of low-fat ground beef prevented fat migration by reducing the probability of fat droplets coalescing and expanding [29]. It is not surprising to find that a higher fat restructured product exhibited the greater cooking loss in present study. Concerning the effect of frozen beef, no significant effect on cooking loss was found ( $p>0.05)$. It indicated that the physical damage caused in muscle cells of the frozen sample by ice crystals upon freezing and subsequently thawing was not an important impact on water loss during cooking of restructured beef steaks.

Raw restructured steak from beef trimmings grade I exhibited lower CIE $\mathrm{L}^{*}$ (lightness) and CIE $\mathrm{b}^{*}$ (yellowness) values with higher CIE $\mathrm{a}^{*}$ (redness) than those from beef trimmings grade II $(\mathrm{p}<0.05)$ (Table 3$)$. The differences in color among beef trimmings related to a higher content of lean meat which implied a greater myoglobin concentration in beef trimmings grade I than grade II. Furthermore, lightness value of cooked steak was significantly influenced by grade of beef trimmings, where grade I showed increased lightness value than grade II $(\mathrm{p}<0.05)$. A more intense discoloration $(\triangle \mathrm{E})$ upon cooking was found in beef trimmings grade II than in grade I $(\mathrm{p}<0.05)$. Similar results have been reported in beef patties with higher fat content having more intense color changes [31]. These authors explained that a lower heme pigments and the formation of protein oxidation induced by higher lipid content during cooking could affect light reflection and yellowness, leading to color deterioration of beef patties [31]. Although there was no effect of freezing on a color of raw steak, it did have an effect on a cooked steak $(p<0.05)$. Cooked steaks processed from frozen beef had lower redness value than those processed from fresh beef $(\mathrm{p}<0.05)$. Denaturation of the globin moiety of the myoglobin molecule takes place during freeze-thaw process, leading to an increased susceptibility of myoglobin to autoxidation and subsequent loss of optimum color presentation [32].

There were no significant differences in shear force of raw restructured steaks among treatments $(p>0.05)$ (Table 3). Variations in the tenderness of cooked beef steaks as indicated by shear force was largely affected by freezing in which the product from frozen beef showed lower shear force than fresh beef $(p<0.05)$. Tenderness of raw meat increased with increasing number of freeze-thaw cycles, which related to the loss of structural integrity caused by ice crystal formation and small intracellular ice crystals and probably by the release of protease enzymes [32]. Generally, WBSF refers to the maximum force required to shear through a sample and used as an index of meat toughness. Moreover, Canto et al [33] evaluated the binding properties of restructured caiman steaks containing MTGase using TPA analysis results. In present study, the effect of freezing on TPA was also more pronounced in raw steaks than in cooked steak (Table 3). Raw steak made from frozen beef showed lower hardness, gumminess, and chewiness, but higher cohesiveness and springiness than those made from fresh beef $(\mathrm{p}<0.05)$, representing a softer texture but a stronger meat binding. Canto et al [33] and Herroero et al [34] reported that the increase in springiness and cohesiveness observed in meat systems containing MTGase can be attributed to the enhanced protein cross-linking between meat particles. Regarding the effect of beef trimmings grade, it largely impacted on hardness among beef samples. Hardness of raw steak processed from beef trimmings grade II tended to lower $(\mathrm{p}<0.07)$ and hardness of its cooked steak was lower $(\mathrm{p}<0.05)$ as compared to beef trimmings grade I. It could be due to the fact that a higher fat level in beef trimmings grade II. The deposition of fat, either intramuscular fat, intrafasicular or intracellular fat, tends to provide a more tender and potentiates the sensation of the tenderness of meat and meat products [29].

\section{Microbial count}

Although there were no significant differences in microbial counts among raw restructured steaks from different treatments, they showed viable counts determined on PCA ranging from 4.72 to $5.40 \mathrm{Log}$ CFU/g for psychrotrophic bacteria and from 3.38 to 3.91 Log CFU/g for mesophilic bacteria depending on treatments, while thermophilic bacterial counts showed a below the detection level (Table 4). The number of psychrophilic bacteria was, on average, 1 log cycle higher than mesophilic bacteria in each sample. These results are in agreement with those reported by Ercolini et al [35] in refrigerated beef. They stated that bacteria developing on meat at chill temperatures are regarded as psychrotrophic populations belonging to microbial genera of both gram-positive, such as lactic acid bacteria, and Gram-negative bacteria, such as Pseudomonas spp. and Enterobacteriaceae [36]. Species of Pseudomonas are particularly involved in the spoilage of meat stored at chill temperatures [37]. After grilling the steaks until the CT reached $71^{\circ} \mathrm{C}$, psychrotrophic and mesophilic bacteria counts of all samples were reduced to an undetectable level.

\section{Sensory evaluation}

Beef trimmings grade influenced some sensory attributes as shown in Table 5. Restructured beef made from beef trimmings grade II exhibited a higher sensory score of tenderness $(p<0.05)$ as well as tending towards higher scores of juiciness and overall acceptability $(\mathrm{p}<0.07)$ compared with those from sample grade I. Berry et al [38] found that the steaks with higher fat levels (18\% and 22\%) were juicier, moister and had greater mouth coating property than lower fat level (10\% and $14 \%)$. Moreover, Iida et al [39] reported that an increase in fat content of cooked beef increased the tenderness, juiciness, and fattiness scores and also enhanced the umami intensity and beef flavor intensity, leading 
Table 4. Microbial counts (Log CFU/g) of restructured beef steaks containing MTGase from different beef trimmings grade and freezing

\begin{tabular}{|c|c|c|c|c|c|c|c|}
\hline \multirow{2}{*}{ Microbial count } & \multicolumn{3}{|c|}{ Beef trimmings } & \multicolumn{3}{|c|}{ Freezing } & \multirow{2}{*}{ SEM } \\
\hline & Grade I & Grade II & $p$-value ${ }^{1)}$ & Fresh & Frozen & $p$-value ${ }^{1)}$ & \\
\hline \multicolumn{8}{|l|}{ Raw samples } \\
\hline Psychrotrophic & $4.72^{2)}$ & 5.40 & 0.071 & 5.18 & 4.84 & 0.093 & 0.093 \\
\hline Mesophile & 3.91 & 3.38 & 0.107 & 3.73 & 3.55 & 0.514 & 0.514 \\
\hline Thermophile & $N D^{3)}$ & ND & - & ND & ND & - & - \\
\hline \multicolumn{8}{|l|}{ Cooked samples } \\
\hline Psychrotrophic & ND & ND & - & ND & ND & - & - \\
\hline Mesophile & ND & ND & - & ND & ND & - & - \\
\hline Thermophile & ND & ND & - & ND & ND & - & - \\
\hline
\end{tabular}

MTGase, microbial transglutaminase; SEM, standard error of mean; ND, not detected.

No interaction effect of beef trimmings $x$ freezing was observed in these analyzed parameters $(p>0.05)$.

${ }^{1)}$ Statistical significance after applying general linear model procedure.

${ }^{2)}$ Values are given as least squared mean.

${ }^{3)}$ Counts below the detection level.

Table 5. Sensory attributes of cooked restructured beef steaks containing MTGase as influenced by beef trimmings grade and freezing

\begin{tabular}{|c|c|c|c|c|c|c|c|}
\hline \multirow{2}{*}{ Attributes } & \multicolumn{3}{|c|}{ Beef trimmings } & \multicolumn{3}{|c|}{ Freezing } & \multirow{2}{*}{ SEN } \\
\hline & Grade I & Grade II & $p$-value ${ }^{1)}$ & Fresh & Frozen & $p$-value ${ }^{1)}$ & \\
\hline Color & $4.20^{2)}$ & 4.41 & 0.316 & 4.37 & 4.25 & 0.589 & 0.15 \\
\hline Appearance & 4.38 & 4.38 & 1.000 & 4.50 & 4.26 & 0.232 & 0.20 \\
\hline Flavor & 4.26 & 4.23 & 0.882 & 4.30 & 4.20 & 0.657 & 0.16 \\
\hline Tenderness & 3.95 & 4.48 & 0.049 & 4.22 & 4.17 & 0.839 & 0.17 \\
\hline Juiciness & 3.70 & 4.35 & 0.064 & 4.03 & 3.87 & 0.277 & 0.17 \\
\hline Overall acceptability & 4.10 & 4.46 & 0.068 & 4.29 & 4.19 & 0.576 & 0.12 \\
\hline
\end{tabular}

MTGase, microbial transglutaminase; SEM, standard error of mean.

No interaction effect of beef trimmings $x$ freezing was observed in these analyzed parameters $(p>0.05)$.

1) Statistical significance after applying general linear model procedure.

${ }^{2)}$ Values are given as least squared mean.

to an improved overall evaluation score. The eating satisfaction of beef usually results from a combination of tenderness, juiciness and flavor [40]. According to present study, the sensory evaluation showed no significant differences among sensory attributes between the fresh and frozen meat $(\mathrm{p}<0.05)$. This meant that the processing could use the meat that has been frozen and then thawed for 1 cycle, which would contribute flexibility to process for industry. The results are in agreement with Rahman et al [41], who observed that the deterioration in sensorial quality was small and significant only when the freeze-thaw cycle was repeated after two or three cycles.

\section{CONCLUSION}

Beef trimmings grade II with possessing high-fat level (16.03\% fat) could be a suitable raw material for processing restructured beef steaks. Although some detrimental effect on cooking loss and discoloration after cooking was observed, higher scores of tenderness, juiciness and overall acceptability were found in restructured steaks processed from beef trimmings grade II than from those made from beef trimmings grade I ( $2.15 \%$ fat). Freezing of beef trimmings could improve the meat binding and soft texture of restructured steak as evaluated by instrumental texture analysis without negatively affecting sensory attributes, allowing flexibility to meat producers.

\section{CONFLICT OF INTEREST}

We certify that there is no conflict of interest with any financial organization regarding the material discussed in the manuscript.

\section{ACKNOWLEDGMENTS}

The authors would like to express their sincere thank to Faculty of Agricultural Technology, KMITL for the financial support, and undergraduate student, Panita Jungwarawit and Wanchalerm Phruksawan for some laboratory assistant.

\section{REFERENCES}

1.Office of Agricultural Economic. Situation of agricultural products and trends in Thailand [Internet]. Office of Agricultural Economic; 2015 [cited 2015 Feb 28]. Available from: http://www.oae.go.th/ download/document_tendency/journalofecon2558.pdf 
2.Kuraishi C, Sakamoto J, Yamazaki K, et al. Production of restructured meat using microbial transglutaminase without salt or cooking. J Food Sci 1997;62:488-90.

3.Lee HG, Lanier TC. The role of covalent cross-linking in the texturizing of muscle protein sols. J Muscle Foods 1995;6:125-38.

4.Antequera T, Pérez-Palacios T, Rodas E, Rodríguez M, Córdoba JJ. Effect of muscle type and frozen storage on the quality parameters of Iberian restructured meat preparations. Food Sci Technol Int 2014; 20:543-54.

5.Sen AR, Karim SA. Effect of meat particle size on quality attributes of restructured mutton steaks. J Food Sci Technol 2003;40:423-5.

6.Farouk MM, Zhang SX, Cummings T. Effect of muscle fiber/fiberbundle alignment on physical and sensory properties of restructured beef steaks. J Muscle Food 2005;16:256-73.

7.Farouk MM, Hall WK, Wieliczko KJ, Swan JE. Processing time and binder effect on the quality of restructured rolls from hot-boned beef. J Muscle Food 2005;16:318-29.

8.Gadekar YP, Sharma BD, Shinde AK, Mendiratta SK. Restructured meat products - production, processing and marketing: A review. Indain J Small Rumin 2015;21:1-12.

9.Heinz G, Hautzinger P. Meat processing technology for small-to medium-scale producers [Internet]. Bangkok: Food and Agriculture Organization of the United Nations Regional Office for Asia and Pacific; 2007 [cited 2015 Feb 28]. Available from: http://www.fao. org/docrep/010/ai407e/AI407E05.htm

10. Sethakul J, Sivapirunthep P. Meat processing. Bangkok, Thailand: Mean Service Supply Ltd., Part; 2012.

11. Savell JW, Branson RE, Cross HR, et al. National consumer retail beef study: Palatability evaluations of beef loin steaks that differed in marbling. J Food Sci 1987;52:517-9.

12. Neely TR, Lorenzen CL, Miller RK, et al. Beef customer satisfaction: Role of cut, USDA quality grade, and city on in-home consumer ratings. J Anim Sci 1998;76:1027-33.

13. Wheeler TL, Miller RK, Savell JW, Cross HR. Palatability of chilled and frozen beef steaks. J Food Sci 1990;55:301-3.

14. Lagerstedt A, Enfält L, Johansson L, Lundström K. Effect of freezing on sensory quality, shear force and water loss in beef M. longissimus dorsi. Meat Sci 2008;80:457-61.

15. Latimer GW. AOAC International. Official methods of AOAC International. 19th ed. Gaithersburg, MD, USA: AOAC International; 2012.

16. Laemmli UK. Cleavage of structural proteins during the assembly of the head of bacteriophage. Nature 1970;227:680-5.

17. Lowry OH, Rosebrough NJ, Farr AL, Randall RJ. Protein measurement with the Folin phenol reagent. J Biol Chem 1951;193:265-75.

18. Bourne MC. Texture profile analysis. Food Technol 1978;32:62-5.

19. Downes FP, Ito K. Compendium of methods for the microbiological examination of foods. 4th ed. Washington, DC, USA: American Public Health Association; 2001.

20. SAS Institute Inc. SAS Version 9.0. Cary, NC, USA: SAS Institute; 2002.

21. Daszkiewicz T, Wajda S, Kondratowicz J. Physico-chemical and sensory properties of meat from Black-and-White and Black-and-Whitex Limousine heifers differing in intramuscular fat content. Anim Sci Pap Rep 2005;23:181-7.

22. Corley RB. A guide to methods in the biomedical sciences. New York, NY, USA: Springer Science+Business Media, Inc.; 2005.

23. Qin XS, Luo SZ, Cai J, et al. Effects of microwave pretreatment and transglutaminase crosslinking on the gelation properties of soybean protein isolate and wheat gluten mixtures. J Sci Food Agric 2016;96: 3559-66.

24. Kumazawa Y, Seguro K, Takamura M, Motoki M. Formation of $\varepsilon-(\gamma-$ glutamyl) lysine cross-link in cured horse mackerel meat induced by drying. J Food Sci 1993;58:1062-4.

25. Tammatinna A, Benjakul S, Visessanguan W, Tanaka M. Gelling properties of white shrimp (Penaeus vannamei) meat as influenced by setting condition and microbial tranglutaminase. LWT Food Sci Technol 2007;40:1489-97.

26. Chaijan M, Panpipat W. Gel-forming ability of mackerel (Rastrelliger Branchysoma) protein isolate as affected by microbial transglutaminas. Walailak J Sci Technol 2010;7:41-9.

27. Yokoyama K, Nio N, Kikuchi Y. Properties and applications of microbial transglutaminase. Appl Microbiol Biotechnol 2004;64:447-54.

28. Tornberg E, Olsson A, Persson K. A comparison in fat holding between hamburgers and emulsion sausages. In: Proceeding of the 35th International Congress of Meat Science and Technology 1989; 1989 August 20-25; Copenhagen, Denmark. pp. 752-9.

29. Desmond E, Troy DJ. Nutrient claims on packaging. In: Jensen WK, Devine C, Dikeman M, editors. Encyclopedia of meat sciences. Oxford, UK: Elsevier; 2004. p. 903-9.

30. Troutt ES, Hunt MC, Johnson DE, et al. Chemical, physical and sensory characterisation of ground beef containing 5 to 30 per cent fat. J Food Sci 1992;57:25-9.

31. Utrera M. Morcuende D, Estévez M. Fat content has a significant impact on protein oxidation occurred during frozen storage of beef patties. LWT Food Sci Technol 2014;56:62-8.

32. Leygonie C, Britz TJ, Hoffman LC. Impact of freezing and thawing on the quality of meat: review. Meat Sci 2012;91:93-8.

33. Canto ACVCS, Costa Lima BRC, Suman SP, et al. Physico-chemical and sensory attributes of low-sodium restructured caiman steaks containing microbial transglutaminase and salt replacers. Meat Sci 2014;96:623-32.

34. Herrero AM, Cambero MI, Ordonez JA, de la Hoz L, Carmona P. Raman spectroscopy study of the structural effect of microbial transglutaminase on meat systems and its relationship with textural characteristics. Food Chem 2008;109:25-32.

35. Ercolini D, Russo F, Nasi A, Ferranti P, Villani F. Mesophilic and psychrotrophic bacteria from meat and their spoilage potential in vitro and in beef. Appl Environ Microbiol 2009;75:1990-2001.

36. Gill CO, Newton KG. The ecology of bacterial spoilage of fresh meat at chill temperatures. Meat Sci 1978:2:207-17.

37. Jay JM, Vilai JP, Hughes ME. Profile and activity of the bacterial biota of ground beef held from freshness to spoilage at $5-7^{\circ} \mathrm{C}$. Inter J Food Microbiol 2003;81:105-11. 
38. Berry BW, Smith JJ, Secrist JL. Effects of fat level on sensory, cooking and instron properties of restructured beef steaks. J Anim Sci 1985; 60:434-9.

39. Iida F, Saitou K, Kawamura T, Yamaguchi S, Nishimura T. Effect of fat content on sensory characteristics of marbled beef from Japanese Black steers. Anim Sci J 2015;86:707-15.
40. Koohmaraie M. Meat tenderness and muscle growth: is there any relationship. Meat Sci 2002;62:345-52.

41. Rahman MH, Hossain MM, Rahman SM, Hashem MA, Oh DH. Effect of repeated freeze-thaw cycles on beef quality and safety. Korean J Food Sci Anim Resour 2014;34:482-95. 